\title{
Effect of Sigma Receptor Ligand Haloperidol in Guinea Pig Heart
}

\author{
M. NOVÁKOVÁ \\ Department of Physiology, Faculty of Medicine, Masaryk University in Brno, \\ Czech Republic \\ Received March 30, 2004 \\ Accepted July 29, 2004
}

\section{Abstract}

Nováková M.: Effect of Sigma Receptor Ligand Haloperidol in Guinea Pig Heart. Acta Vet. Brno 2004, 73: 313-320.

Sigma receptors represent a group of enigmatic binding sites with many functions in different tissues. In rat heart, they are responsible for modulation of cardiac contractility. They are also responsible for some adverse side effects of certain psychotropic drugs on cardiovascular system. In this study, the effect of sigma receptor ligand haloperidol on guinea pig heart multicellular preparations was studied. Its positive inotropic effect previously described in rat cardiomyocytes was confirmed in left atria and papillary muscles isolated from the right ventricles (an increase of the twitch amplitude by $36 \%$ to $123 \%$ in comparison with the control period in atria and by $9 \%$ to $46 \%$ in ventricular preparations; all values were statistically significant when compared to control in atrial preparations, but only in the first five min of perfusion in papillary muscles). Also desensitisation process previously reported in rat myocardium after repeated exposure to haloperidol was confirmed (although not statistically significant). The normalized course of mechanical restitution curve was not changed during perfusion with haloperidol. It is concluded that its positive inotropic effect is very likely mediated via increased cytosolic availability of calcium.

Cardiac sigma receptor, contractility, mechanical restitution, desensitisation

Psychotropic drugs quite often exert marked cardiac side effects (increase in blood pressure, arrhythmias, palpitations and even sudden cardiac death), mainly mediated by central and autonomic nervous systems. Some of them are, however, caused also by direct effect of different compounds on cardiac tissue. Sigma receptors are among the binding sites responsible for these direct effects and many sigma ligands belong to different groups of drugs used in everyday clinical practice for management of pain, agitated delirium, treatment of psychoses, etc.

The sigma receptors were first reported in central nervous system. Initially, they were considered a mere subtype of the opioid receptor family, but later they were conclusively defined by binding studies as distinct from any other known class of receptors. Since, they have been found also in many non-neural, peripheral tissues (immune system, digestive tract, endocrine and reproductive systems and excretory system, myocardium, etc.) in various species, including humans. They are present in many tumours and metastases in high densities. Three subtypes of these receptors are reported - sigma1, sigma2 and sigma3 (reviewed by Nováková 1998).

Although sigma receptor has been repeatedly cloned in several tissues and species (Hanner et al. 1996; Kekuda et al. 1996; Seth et al. 1998), identification of its endogenous ligand has not yet been successful. Among many candidates, progesterone takes a prominent place.

In cardiac tissue, modulation of contractility by sigma receptor ligands was first reported in rat neonatal cultured cardiomyocytes (Ela et al. 1994). Later, sigma receptors were found in the membranes of adult rat ventricular cardiomyocytes (Nováková et al. 
1995). Also data on the effects of sigma ligands in rat isolated hearts have been reported (Maslov et al. 1997, 1999; Nováková et al. 2001) and on desensitisation of sigma receptors in heart muscle by repeated treatment with sigma ligands (Nováková et al. 2001; Ela et al. 1996).

The cardiac effects of sigma ligands thus have been studied so far exclusively on rat heart, which is well-known to be rather exceptional among the mammalian species. The aim of this study was to investigate the effect of haloperidol in guinea pig multicellular heart preparations. This model was chosen since this experimental set-up is reliable and the experimental conditions can be strictly controlled.

\section{Materials and Methods}

In the study 19 left atria and 15 papillary muscles from the right ventricle of male guinea pigs were included. The body weight of animals varied from 230 to 360 (average, 295 \pm 28 ) grams. The experiments were restricted to males to exclude possible effect of progesterone on female myocardium.

The animals under deep ether anaesthesia were sacrificed by cervical dislocation. The chest was quickly opened, the heart immediately removed and placed in a preparation bowl with a cold $\left(5^{\circ} \mathrm{C}\right) \mathrm{Krebs}-\mathrm{Henseleit}$ solution of the following composition: $\mathrm{NaCl}, 118 \mathrm{mM} ; \mathrm{NaHCO}_{3}, 24 \mathrm{mM} ; \mathrm{KCl}, 4.2 \mathrm{mM} ; \mathrm{KH}_{2} \mathrm{PO}_{4}, 1.2 \mathrm{mM} ; \mathrm{MgCl}_{2}, 1.2 \mathrm{mM} ; \mathrm{CaCl}_{2}$, $1.2 \mathrm{mM}$; and glucose, $5.5 \mathrm{mM}$. The right ventricle was opened and all suitable papillary muscles removed. Then, the left auricle strip was cut off and placed together with the right ventricle papillary muscle in the perfusion bath (Fig. 1).

A

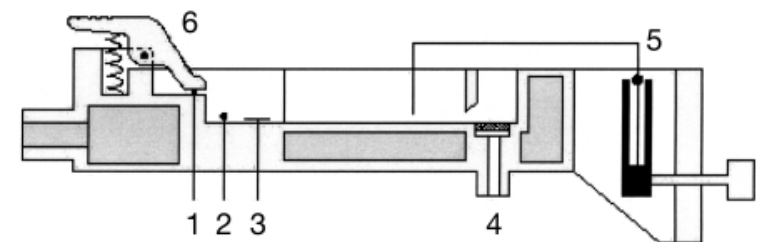

B

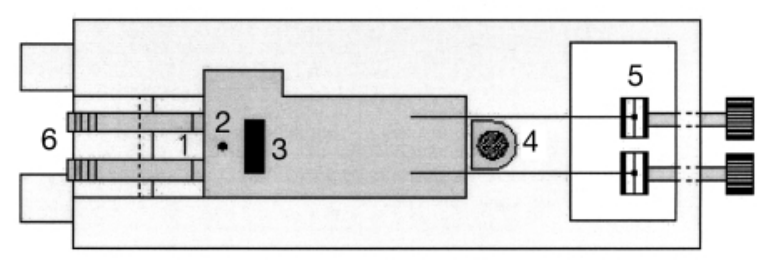

Fig. 1. Horizontal perfusion bath for heart multicellular preparations (A, side view; B, from above). 1. stimulation electrodes; 2. thermometer; 3. grounding electrode; 4. bubbling; 5 . tensometers; 6 . clips.

We employed a horizontal, plastic, double-walled, thermostatically controlled bath for pharmacological studies. It contains a pair of stimulation electrodes at the bottom, one for stimulation (under the clips that held the preparations), the other for grounding. The bath was filled with $10 \mathrm{ml} \mathrm{Krebs-Henseleit} \mathrm{solution} \mathrm{aerated} \mathrm{with} \mathrm{mixture}$ of $\mathrm{O}_{2}$ and $\mathrm{CO}_{2}(95: 5 \%)$. Both muscles were fixed by a clip at one end and attached to a mechano-electric transducer by a thread bound to its opposite end. Simultaneous recording of the tension generated by the preparations was performed under isometric conditions.

The signals were amplified and digitised at sampling rate of $250 \mathrm{~Hz}$ by a one-channel bipolar 16-bit A/D converter. The specialised software allowed simultaneous 30-min record of two trends - maximal and minimal tension of the preparations after stimulus and up to ten 15-second snap-shots with detailed (sampling period of 4 $\mathrm{ms}$ ) recording of stimulated twitches. The recorded data were provided with identification labels, saved in archive files, exported into ASCII and worked out in Excel.

The effects of specific sigma receptor ligand haloperidol on the amplitude of twitch and on the restitution of contractility in both atrial and ventricular guinea pig heart preparations were investigated. The experiments were carried out at $30^{\circ} \mathrm{C}$ and fluctuations in temperature did not exceed $0.5^{\circ} \mathrm{C}$. The preparations were stimulated with $1 \mathrm{~ms}$ pulses of twice the current threshold. Basic stimulation frequency was $1 \mathrm{~Hz}$ throughout the experiments. 


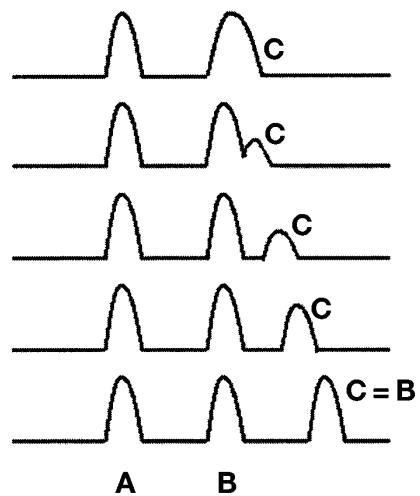

Fig. 2. The experimental protocol for construction the mechanical restitution curve. A, B - last two steady-state contractions in a train of regular stimuli. $\mathrm{C}$ - contractions in response to single stimuli of variable prematurity. The amplitudes of the successive premature contractions (C) form the restitution curve.

Initially, the preparations were stimulated for 30-45 min. At the end of this period control contractions were recorded. Then the contractions of variable prematurity were recorded according to the protocol (Fig. 2) and the mechanical restitution curve was constructed. Next, sigma receptor ligand haloperidol at a concentration $10 \mathrm{nM}$ was administered to the bath for $30 \mathrm{~min}$. Snap-shots of 15 contractions at basal rate $(1 \mathrm{~Hz})$ were recorded after $1,3,5,10,15,20,25$ and $30 \mathrm{~min}$. Then, the stimulation protocol for assessment of drug affected restitution curve was repeated. This protocol was employed once again after 15 min washout with KrebsHenseleit solution. Eventually, haloperidol at the same concentration was administered to the bath for the second time in order to test the possible desensitisation.

Obtained data were tested for normality by the means of KolmogorovSmirnov test. Statistical significance was assessed using one-sample $t$-test, two sample $t$-test or analysis of variance (ANOVA). All statistical analyses were two-sided and performed at the 5\% significance level.

\section{Results}

We observed a marked positive inotropic effect previously described in rat ventricular cardiomyocytes in all experiments. In atria, an increase of the twitch amplitude by $36 \%$ to $123 \%$ in comparison with the control period (average of control twitches amplitudes represents $100 \%$ ), with the maximum effect lasting for the first $5 \mathrm{~min}$ of perfusion. All values were statistically significant when compared to control. In ventricular preparations, the increase of contraction by $9 \%$ to $46 \%$ peaked during the first minute of perfusion (Fig. 3). The increase was statistically significant (compared to control values) only in the first five min of perfusion with haloperidol.

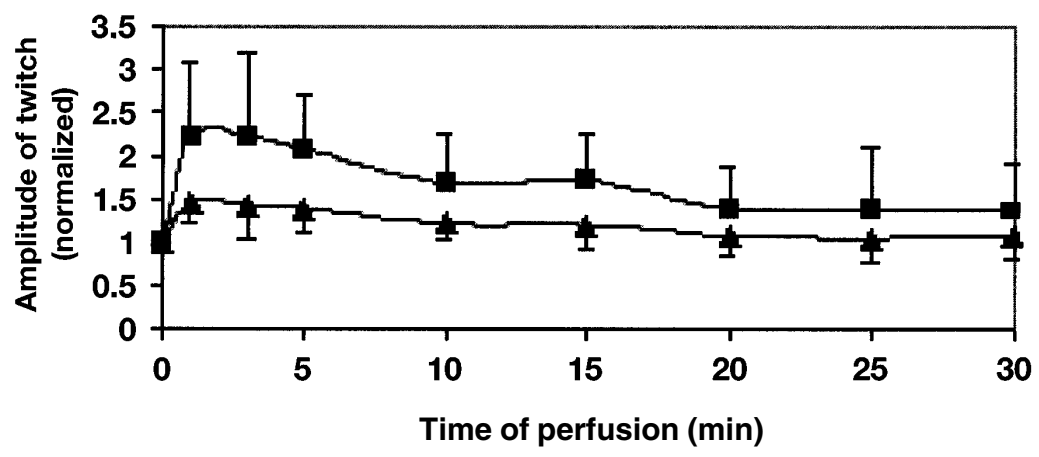

$\rightarrow-$ atria $\longrightarrow$ ventricles

Fig. 3. Time course of the effect of sigma ligand haloperidol on normalized contraction amplitudes of guinea pig atria and papillary muscles. Temperature, $30{ }^{\circ} \mathrm{C}$; stimulation frequency, $1 \mathrm{~Hz}$. Mean $\pm \mathrm{SD}$ of 15 experiments. Wash-out not shown.

The second administration of haloperidol caused a positive inotropic effect in both preparations again. In atrial preparations, however, this effect was attenuated in the whole course of perfusion (increase of contractions by $9 \%$ to $94 \%$ in comparison with control period, with a maximum effect in the third minute of perfusion), (Fig. 4). When 
comparing the first and the second haloperidol administration, no significant difference was found.

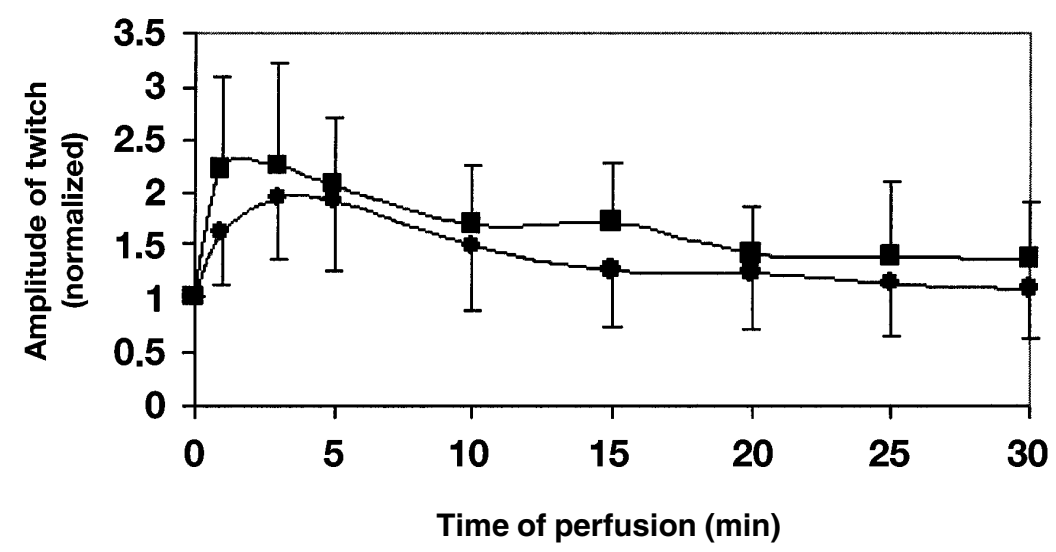

$\rightarrow-1$. administration $\rightarrow$ 2. administration

Fig. 4. The effect of two administrations of haloperidol $(10 \mathrm{nM})$ on contractions of guinea pig left atria. Temperature, $30{ }^{\circ} \mathrm{C}$; stimulation frequency, $1 \mathrm{~Hz}$. Normalized mean $\pm \mathrm{SD}$ from 19 experiments. Wash-out not shown.

In right ventricular papillary muscles, the positive inotropic effect was attenuated more clearly during the second administration of haloperidol - the increase of contractions ranged from 9 to $38 \%$, with the maximum between the $10^{\text {th }}$ and the $30^{\text {th }}$ minute of perfusion), (Fig. 5). Again, no significant difference between the first and the second haloperidol administration was found.
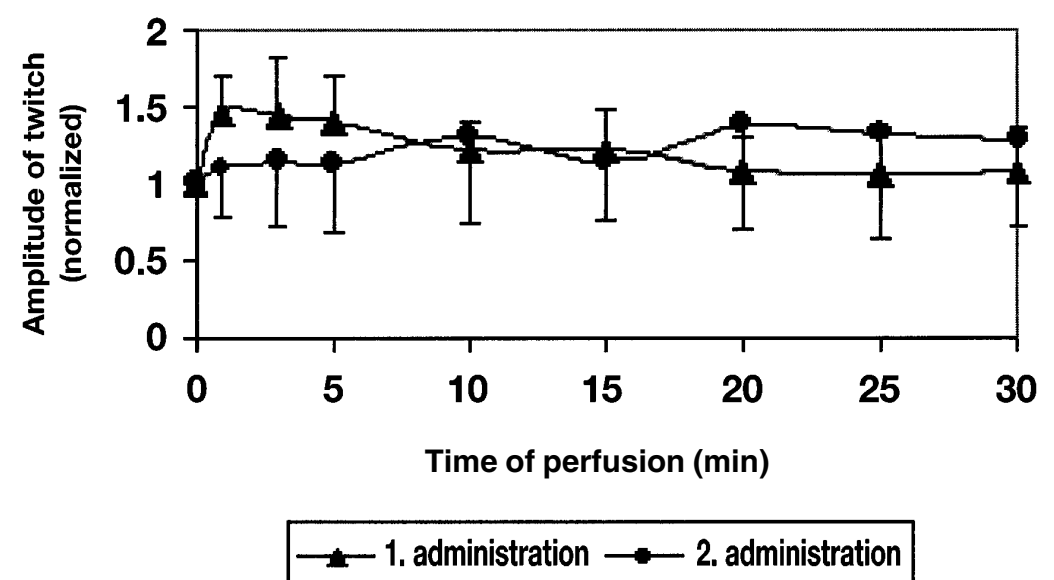

Fig. 5. The effect of haloperidol $(10 \mathrm{nM})$ on right heart papillary muscles. For legend see Fig. 4. Normalized mean \pm SD from 15 experiments. 
The pattern of mechanical restitution was not altered in either preparation under the effect of haloperidol (Figs 6,7). There were no significant differences between mechanical restitution curves in either situation or preparation.

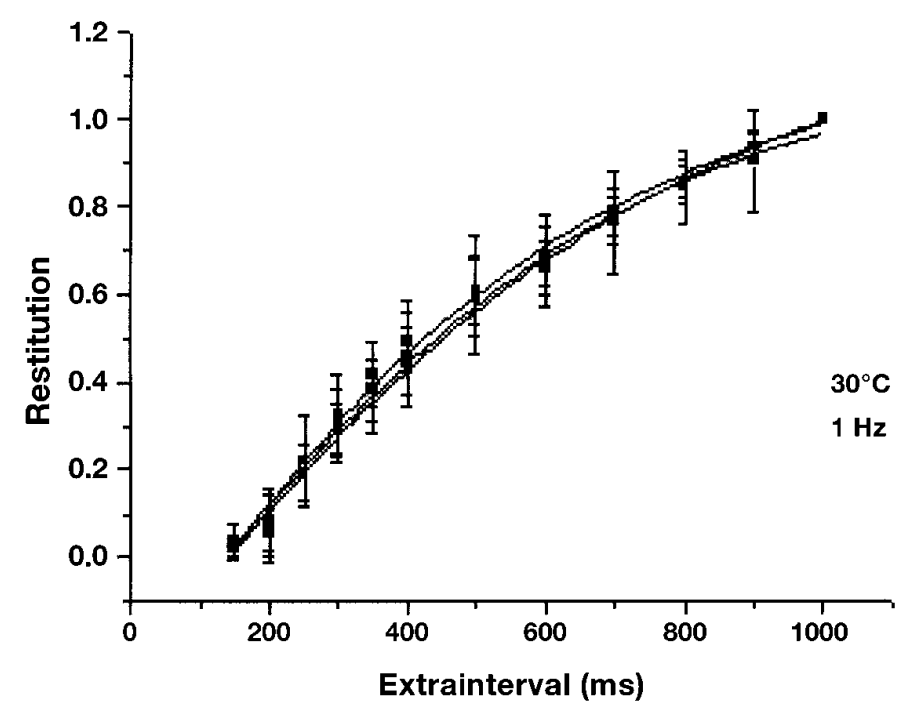

Fig. 6. The normalized mechanical restitution of left atrial muscles under control conditions, after $30 \mathrm{~min}$ of perfusion with haloperidol and after15 min of wash-out. Abscissa, extrainterval, period between a regular and a premature stimulation pulse. Temperature, $30{ }^{\circ} \mathrm{C}$; basal stimulation frequency, $1 \mathrm{~Hz}$. Mean $\pm \mathrm{SD}$ from 19 experiments.

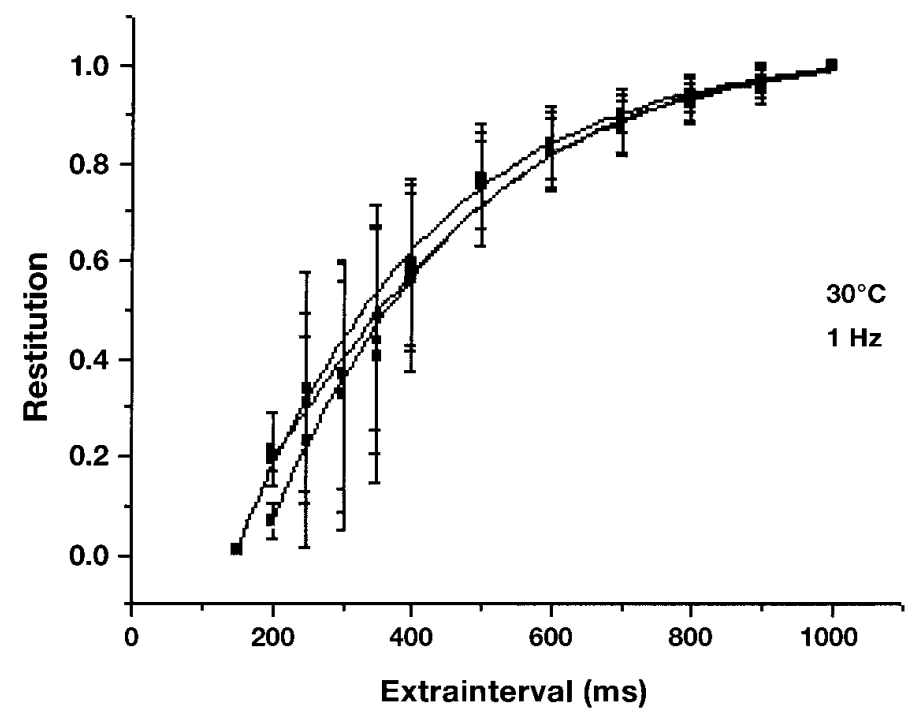

Fig. 7. Mechanical restitution of right heart papillary muscles. For legend see Fig. 6 . Normalized mean \pm SD from 15 experiments. 


\section{Discussion}

In this study, the effect of haloperidol, a typical sigma receptor ligand was investigated in guinea pig heart multicellular preparations. Haloperidol is a psychotropic drug used in everyday clinical practice for treatment of psychoses like schizophrenia or severe agitated delirium. Its cardiac side effects - arrhythmias such as torsade de pointes, ventricular fibrillation and other life-threatening complications and even cardiac arrest - are well known and were reported repeatedly (Di Salvo and O' Gara 1995; Cruz et al. 1983; Tis dale et al. 1991; Lawrence and Nasraway 1997). The concentration used in our experiments was $10 \mathrm{nM}$. It was chosen on the basis of our previous experiments (Nováková et al. 1995) where binding studies revealed that $\mathrm{K}_{\mathrm{i}}$ for sigma receptors in rat cardiac myocytes is $6.1 \pm$ $1.3 \mathrm{nM}$. Since many drugs in clinical use bind to sigma receptors with nanomolar affinities (certain neuroleptics, monoamine oxidase inhibitors and several antihistamines - Vilner et al. 1995), we consider this concentration relevant.

Since the so far data have been obtained in myocytes and in preparations from rat heart which is quite exceptional from many points of view, the effect of sigma binding on the contractility of guinea pig heart multicellular preparations was examined. Inotropic effect was first described in neonatal rat cultured cardiomyocytes (Ela et al. 1994): exposure to nanomolar concentrations of the sigma receptor ligands (+)-3-PPP ((+)-3-hydroxyphenyl$N$-(1-propyl)piperidine), (+)-pentazocine and haloperidol, induced specific pattern of changes in twitch amplitude of the cardiomyocytes, consisting of an initial decrease, followed by a transient increase and a final decrease of amplitude.

In similar experiments with adult rat isolated ventricular myocytes, the initial decrease of the amplitude of twitch was absent and the increase in the amplitude was much higher in most of the cells (Nováková et al. 1995). In part of the cells exposed to low concentrations of sigma receptor ligands, only a decrease of the contractile response was observed. In analogous experiments carried out with highly selective, high affinity sigma receptor ligands BD-737 (1S, 2R-cis-N- [2-(3,4-dichlorophenyl)ethyl] - $N$-methyl-2- (1-pyrrolidinyl) cyclohexylamine) and BD-1047 (N- [2-(3,4-dichlorophenyl)ethyl] - N,N',N' trimethylethylenediamine) the positive inotropic effect was also observed (Nováková et al. 1998). All these data were obtained with nanomolar concentrations of sigma ligands. These experiments brought evidence in support of the idea that the cardiotropic effects of psychotropic drugs used are due to binding to specific receptors and not by a cross-talk between the different receptor systems.

In all the above mentioned experiments fluctuations of the response to sigma ligands was present. This typical pattern can be observed also in the time course of the effect of haloperidol in guinea pig heart preparations (Fig. 3).

Recently, modulation of the negative inotropic effect of haloperidol by drugs with positive inotropic effects in isolated rabbit heart has been reported (Hatip-Al-Khatib and Bolukbasi-Hatip 2002). However, the negative inotropic effect was elicited by micromolar concentration of haloperidol, which is by three orders of magnitude higher than the concentration used in our study. In such case, other receptor systems may play a role in this effect (e.g. dopaminergic receptors).

Desensitisation of sigma receptors was reported in neonatal cultured rat cardiomyocytes (Ela et al. 1996) and in neurons (In oue et al. 2000). In isolated rat hearts perfused according to Langendorff, the exposure to haloperidol caused prominent ventricular ectopic activity and bigeminy in all hearts. The occurrence of arrhythmias was significantly lower during the second haloperidol administration in support of the concept of desensitisation (Nováková et al. 2001). In the present study, repeated treatment of guinea pig heart preparations with haloperidol seems to trigger similar desensitisation process as described previously in rat heart muscle. However, attenuation of positive inotropic effect caused by 
the second haloperidol administration was statistically not significant. Thus, the desensitisation of sigma receptors in guinea pig heart deserves more investigation.

The mechanical restitution curve is a sensitive tool for estimation of heart preparation viability. Its course is not changed under the effect of haloperidol and does not change even during long lasting desensitisation experiments. We can assume that positive inotropic effect of sigma ligand is mediated via increased cytoplasmic $\mathrm{Ca}^{2+}$ concentration as previously reported in rat myocardium.

Thus, the positive inotropic effect of sigma receptor ligand haloperidol was confirmed also in guinea pig atrial and right ventricular heart preparations. Attenuation of this positive inotropic effect of haloperidol in the case of repeated exposure leads to the conclusion that sigma receptors in guinea pig heart probably undergo a desensitisation process previously reported in rat myocardium.

\section{Účinek sigma ligandu haloperidolu na srdce morčete}

Sigma receptory představují skupinu méně prozkoumaných vazebných míst s rozmanitými funkcemi v mnoha tkáních. U srdce potkana se podílejí na jemné modulaci kontraktility. Jsou také odpovědné za nežádoucí kardiovaskulární vedlejší účinky některých psychotropních látek. V této práci byl zkoumán účinek ligandu sigma receptorů haloperidolu na multicelulární preparáty ze srdce morčete. Pozitivní inotropní účinek této látky popsaný dříve u kardiomyocytů potkana byl potvrzen i u levých síní a papilárních svalů izolovaných z pravých komor (nárůst amplitudy stahu mezi 36\% a 123\% oproti kontrole u síní a mezi $9 \%$ a $46 \%$ u komorových preparátů; všechny hodnoty statisticky významné u síní, ale pouze $\mathrm{v}$ prvních 5 minutách perfuze u papilárních svalů). Zároveň byla potvrzena i desensitizace sigma receptorů, která byla popisována u srdce potkana po opakované aplikaci haloperidolu (statisticky nesignifikantní). Normalizovaná křivka mechanické restituce se pod vlivem haloperidolu nemění. Positivně inotropní účinek haloperidolu je pravděpodobně zprostředkován zvýšením cytosolické dostupnosti vápníku.

\section{Acknowledgement}

The author wishes to express her gratitude to Prof. Pavel Bravený for fruitful discussions of the results and to Mrs. Branislava Vyoralová for her excellent technical help.

The animals were treated in consent with animal care and use regulations of the Czech Republic.

This work was supported by grant No. 305/04/1385 from the Grant Agency of the Czech Republic.

\section{References}

CRUZ, FG, THIAGARAJAN, D, HARNEY, JH 1983: Neuroleptic malignant syndrome after haloperidol therapy. South Med J 76: 684-686

Di SALVO, TG, O’GARA, PT 1995: Torsade de pointes caused by high-dose intravenous haloperidol in cardiac patient. Clin Cardiol 18: 285-290

ELA, C, BARG, Z, VOGEL, Y et al. 1994: Sigma receptor ligands modulate contractility, $\mathrm{Ca}^{++}$influx and beating rate in cultured cardiac myocytes. J Pharm and Exp Ther 269: 1300-1309

ELA, C, HASIN, Y, EILAM, Y 1996: Apparent desensitization of a sigma receptor sub-population in neonatal rat cardiac myocytes by pre-treatment with sigma receptor ligands. Eur J Pharmacol 295: 275-280

HANNER, M, MOEBIUS, FF, FLANDORFER, A et al. 1996: Purification, molecular cloning and expression of the mammalian sigma1-binding site. Proc Nat Acad Scien USA 93: 8072-8078

HATIP-Al-KHATIB, I, BOLUKBASI-HATIP, F 2002: Modulation of the negative inotropic effect of haloperidol by drugs with positive inotropic effects in isolated rabbit heart. Pharmacology 66: 19-25

INOUE, A, SUGITA, S, SHOJI, H et al. 2000: Repeated haloperidol treatment decreases sigma-1 receptor binding but does not affect its mRNA levels in the guinea pig or rat brain. Eur J Pharm 401: 307-316

KEKUDA, R, PRASAD, PD, FEI, YJ et al. 1996: Cloning and functional expression of the human type 1 sigma receptor (hSigmaR1). Bioch Biophys Res Com 229: 553-558

LAWRENCE, KR, NASRAWAY, SA 1997: Conduction disturbances associated with administration of butyrophenone antipsychotics in the critically ill: a review of the literature. Pharmacotherapy 17: 531-537 
MASLOV, LN, KRYLATOV, AB, LISHMANOV, YuB 1997: Antiarrhythmic effect of the selective sigma receptor antagonist DuP734 [1-(cyclopropylmethyl)-4-(2'(4"'-fluorophenyl)-2'-oxoethyl)piperidine Hbr]. Eksp Klin Farmak 60: 24-26

MASLOV, LN, LISHMANOV, YuB, BOGOMAZ, SA et al. 1999: Dependence of the cardiac pump function on functional activity of sigma receptors under condition of reperfusion. Rus J Physiol 85: 1396-1408

NOVÁKOVÁ, M, PROVAZNÍK, I, BARDOŇOVÁ, J 2001: Wavelet analysis of the effect of sigma ligand haloperidol on isolated rat heart. IFMBE Proceedings, Medicon, Zagreb. pp. 418-421

NOVÁKOVÁ, M 1998: Sigma receptors: With special reference to cardiac muscle. Exper Clin Cardiol 3: 113-120

NOVÁKOVÁ, M, ELA, C, BARG, J et al. 1995: Inotropic action of sigma receptor ligands in isolated cardiac myocytes from adult rats. Eur J Pharm 286: 19-30

NOVÁKOVÁ, M, ELA, C, BOWEN, WD 1998: Highly selective sigma receptor ligands elevate inositol 1,4,5trisphosphate production in rat cardiac myocytes. Eur J Pharm 353: 315-327

SETH, P, FEI, YJ, LI, HW et al. 1998: Cloning and functional characterization of a sigma receptor from rat brain. J Neurochem 70: $922-931$

TISDALE, JE, KAMBE, JC, CHOW, MS et al. 1991: The effect of haloperidol on ventricular fibrillation threshold in pigs. Pharmacol Toxicol 69: 327-329

VILNER, BJ, JOHN, CS, BOWEN, WD 1995: Sigma-1 and sigma-2 receptors are expressed in a wide variety of human and rodent tumor cell lines. Cancer Research 55: 408-413 